\title{
FORMULASI, UJI STABILITAS FISIK DAN KOMPATIBILITAS PRODUK KOSMETIK ANTI-AGING DALAM SEDIAAN SERUM PUDDING
}

\author{
Farhamzah*, Aeni Indrayati \\ Fakultas Farmasi, Universitas Buana Perjuangan Karawang \\ *farhamzah@ubpkarawang.ac.id \\ fm17.aeniindriyati@mhs.ubpkarawang.ac.id
}

\begin{abstract}
ABSTRAK
Serum adalah salah satu sediaan kosmetik berbentuk gel yang digunakan untuk produk anti-aging dan bentuk gel dari sediaan bisa dibuat lebih menarik sebagai variasi dari bentuk serum yang sudah ada. Maka dilakukan penelitian formulasi produk antiaging dengan sediaan berbentuk serum yang mempunyai tekstur seperti Pudding. Formulasi menggunakan bahan baku polimer dengan konsentrasi 5\% dengan perbedaan formula pada konsentrasi parfum. Hasil formulasi dilakukan uji sediaan berupa pemeriksaan organoleptik, $\mathrm{pH}$, viskositas, kelembaban, after feel, rasa lengket, rasa panas, rasa gatal, Uji Stabilitas dan Uji Kompabilitas selama 12 minggu. Hasil penelitian menunjukkan bahwa formula yang tidak menggunakan parfum memberikan hasil stabilitas dan kompabilitas yang baik.
\end{abstract}

Kata Kunci : Stabilitas Fisik, Kompatibilitas, Anti-Aging, Serum Pudding

\begin{abstract}
Serum is one of the gel-shaped cosmetic preparations used for anti-aging products and the gel form of the preparation can be made more attractive as a variation of the existing serum form. Then do research on anti-aging product formulations with serum-shaped preparations that have a texture like Pudding. The formulation uses a polymer raw material with a concentration of $5 \%$ with different formulas at the Perfume concentration. The results of the formulations were tested in the form of organoleptic tests, $p H$, viscosity, humidity, after feel, stickiness, burning sensation, itching, Stability Test and Compatibility Test for 12 weeks. The results show that formulas that do not use perfume provide good stability and compatibility results.
\end{abstract}

Keywords: Stability Test, Compatibility Test, Anti-Aging, Pudding Serum 


\section{PENDAHULUAN}

Kosmetik adalah bahan atau sediaan yang dimaksudkan untuk digunakan pada bagian luar tubuh manusia (epidermis, rambut, kuku, bibir dan organ genital bagian luar) atau gigi dan mukosa mulut terutama untuk membersihkan, mewangikan, mengubah penampilan dan atau memperbaiki bau badan atau melindungi atau memelihara tubuh pada kondisi baik (BPOM, 2003; Tranggono dan Latifah. 2007). Bahan kosmetika secara definisi adalah ilmu yang mempelajari kandungan bahan dan manfaat yang dihasilkan oleh pemakaian bahan tersebut terhadap penampilan dan kecantikan seseorang. Pengkajian bahan ini dapat dilakukan secara fisik, organik dan anorganik. (Primadiati, 2001). Anti-aging atau disebut juga anti penuaan merupakan produk kosmetik topikal yang mampu mengobati atau menghilangkan gejala penuaan pada kulit yang disebabkan oleh sinar UV matahari (fotoaging) atau produk yang dapat mengurangi atau memperlambat timbulnya gejala-gejala fotoaging (Barel et al., 2009). Fungsi anti-aging adalah untuk menyuplai antioksidan bagi jaringan kulit, menstimulasi proses regenerasi sel-sel kulit, menjaga kelembaban dan elastisitas kulit, dan merangsang produksi kolagen. Manfaat anti-aging antara lain mencegah kerusakan degeneratif yang menyebabkan kulit terlihat kusam dan keriput, membuat kulit tampak sehat, cerah, elastis, dan awet muda (Muliyawan dan Surana, 2013).

Salah satu dari bentuk sediaan kosmetik yang telah berkembang akhir - akhir ini adalah serum. Serum merupakan sediaan dengan viskositas rendah, karena viskositasnya yang rendah serum dikategorikan sebagai sediaan emulsi. Serum memiliki kelebihan yaitu memiliki konsentrasi bahan aktif tinggi sehingga efeknya lebih cepat diserap kulit, dapat memberikan efek yang lebih nyaman dan lebih mudah menyebar dipermukaan kulit karena viskositasnya yang tidak terlalu tinggi (Kurniawati, 2018). Serum Pudding adalah sediaan gel seperti Pudding yang dibuat dari bahan Polimer. Polimer yang digunakan adalah polimer larut air yang memiliki ikatan uretan dalam struktur. Ini mengaitkan molekul air dan menunjukkan efek penebalan pada air dengan membentuk gel air. Ini digunakan untuk kosmetik sebagai gelator. Kandungan yang ada dalam Polimer ini adalah PEG-240/HDI Copolymer Bis-Decyltetradeceth-20 Ether, Butylene Glycol, Air, Tocopherol dan Pottasium Laurate. Kelebihan dari serum Pudding selain lebih mudah dalam pemakaian juga sediaan ini akan kembali rata setelah diambil oleh jari tangan. 


\section{METODE PENELITIAN}

Metode yang digunakan dalam penelitian ini adalah metode experiment dengan menggunakan sampel polimer sebagai bahan baku serum Pudding.

\section{III.1 Alat dan Bahan}

Alat yang digunakan Mixer homogenizer, Hot plate, stirer, timbangan analitik, thermometer gelas, plastic wrap, batang pengaduk, spatula, beaker glass $250 \mathrm{ml}$, botol semprot. Bahan yang digunakan Polimer, $\mathrm{Na}_{4}$ EDTA, Sodium Hyaluronate, Vitamin E, Apple Stemcell, Skin Tightener, Astaxanthin, CM Glucan, Irricalmin, Hedipin RH400, Verstatil PC, Parfum, Honey Ekstract, Citric Acid dan Air Reverse Osmosis.

\section{III.2 Prosedur Percobaan}

\section{Pembuatan Sediaan Serum Pudding}

Pembuatan Serum Pudding anti-aging dilakukan dengan memasukkan Na4EDTA dan Sodium Hyaluronate kedalam beaker glass yang berisi air, kemudian dipanaskan sampai suhu $80^{\circ} \mathrm{C}$ sambil diaduk menggunakan homogenizer lalu masukkan Polimer kedalam campuran kemudian diaduk menggunakan homogenizer selama 15 menit sampai mengembang dan berbentuk gel dan didinginkan sampai suhu $40^{\circ} \mathrm{C}$. Masukkan Hedipin, Versatil PC dan Parfum yang sudah dicampur terlebih dahulu kedalam campuran utama, aduk sampai homogen. Tambahkan bahan baku lainnya satu persatu dan diaduk sampai homogen, kemudian didinginkan sampai suhu $30^{\circ} \mathrm{C}$.

Tabel 1.Formula Sediaan Serum Pudding

\begin{tabular}{cccc}
\hline Nama Zat & F1 (\%) & F2 (\%) & F3 (\%) \\
\hline Polimer & 5 & 5 & 5 \\
\hline Na4EDTA & 0,1 & 0,1 & 0,1 \\
\hline Sodium Hyaluronate & 0,2 & 0,2 & 0,2 \\
\hline Air RO & 81,076 & 80,926 & 80,426 \\
\hline Vitamin E & 0,05 & 0,05 & 0,05 \\
\hline Apple Stemcell & 2 & 2 & 2 \\
\hline Skin Tightener & 7 & 7 & 7 \\
\hline Astaxanthin & 0,05 & 0,05 & 0,05 \\
\hline CM Glucan & 1 & 1 & 1 \\
\hline Irricalmin & 0,5 & 0,5 & 0,5 \\
\hline Hedipin RH400 & 2 & 2 & 2 \\
\hline Verstatil PC & 0,5 & 0,5 & 0,5 \\
\hline Parfum & 0 & 0,15 & 0,2 \\
\hline
\end{tabular}




\begin{tabular}{cccc}
\hline Honey Ekstrak & 0,5 & 0,5 & 0,5 \\
\hline Citric Acid & 0,024 & 0,024 & 0,024 \\
\hline Total & 100 & 100 & 100 \\
\hline
\end{tabular}

\section{Evaluasi Hasil Serum Pudding}

Evaluasi serum Pudding meliputi uji organoleptis, viskositas, kelembaban, After feel, rasa lengket, rasa panas, rasa gatal, viskositas dan $\mathrm{pH}$.

\section{Uji Stabilitas}

Uji stabilitas produk baru pada batch percobaan dilakukan dengan metode Stabilitas Dipercepat selama 12 minggu (BPOM, 2010) dengan pemeriksaan organoleptis (Bentuk, Warna, Bau), $\mathrm{pH}$ dan viskositas. Uji Stabilitas dilakukan selama 12 minggu (minggu ke-0, minggu ke-1, minggu ke-2, minggu ke-3, minggu ke-4, minggu ke-8 dan minggu ke-12) dengan penyimpanan di suhu kamar, suhu $40^{\circ} \mathrm{C}$ dan di bawah sinar matahari.

\section{Uji Kompatibilitas}

Uji kompabilitas produk dilakukan dengan menggunakan kemasan yang akan digunakan pada produk akhir yaitu pada kemasan pot untuk memastikan tidak ada reaksi antara isi produk dengan kemasannya. Kemudian diuji selama 12 Minggu (minggu ke-0, minggu ke-1, minggu ke-2, minggu ke-3, minggu ke-4, minggu ke-8 dan minggu Ke-12) dengan penyimpanan di suhu kamar, suhu $40^{\circ} \mathrm{C}$ dan dibawah sinar matahari. Pada uji kompabilitas dilakukan juga uji penyusutan berat produk.

\section{HASIL DAN PEMBAHASAN}

Hasil evaluasi organoleptik untuk formula yang dibuat produk berwarna orange alami dari bahan baku astaxhantin dengan bau tidak berbau untuk formula 1 dan bau parfum untuk formula 2 dan 3. Konsentrasi Polimer yang digunakan sebanyak 5\% memberikan kekentalan seperti gel dengan tekstur seperti Pudding, bentuk gel atau Pudding yang dihasilkan akan rata, dan akan kembali rata setelah pengambilan oleh jari. Produk serum pudding yang dihasilkan memberikan efek melembabkan pada kulit, mudah meresap, tidak menimbulkan rasa lengket, rasa panas dan rasa gatal. Hasil pemeriksaan $\mathrm{pH}$ dan Viskositas pun memberikan hasil yang sesuai spesifikasi, untuk 
formula yang tidak memakai parfum lebih kental dibanding yang memakai parfum. Hasil pemeriksaan dapat dilihat pada tabel 2 dan gambar 1.

Tabel 2. Hasil Pemeriksaan Awal Sediaan

\begin{tabular}{ccccc}
\hline \multirow{2}{*}{ Evaluasi } & \multirow{2}{*}{ Persyaratan } & \multicolumn{3}{c}{ Hasil pengamatan } \\
\cline { 3 - 5 } & & F1 & F2 & F3 \\
\cline { 3 - 5 } Bentuk & Pudding & Pudding & Pudding & Pudding \\
\hline Warna & Orange & Orange & Orange & Orange \\
\hline Bau & Khas & Khas & Khas & Khas \\
\hline Kelembaban & Terasa Lembab & Terasa Lembab & Terasa Lembab & Terasa Lembab \\
\hline After feel & Sesuai & Sesuai & Sesuai & Sesuai \\
\hline Rasa Lengket & Tidak Terasa & Tidak Terasa & Tidak Terasa & Tidak Terasa \\
\hline Rasa Panas & Tidak Terasa & Tidak Terasa & Tidak Terasa & Tidak Terasa \\
\hline Rasa Gatal & Tidak Terasa & Tidak Terasa & Tidak Terasa & Tidak Terasa \\
\hline Viskositas & $>2000.000$ & $288.000(4 / 1,5 / 67 \%)$ & $255.000(4 / 1,5 / 67 \%)$ & $240.000(4 / 1,5 / 67 \%)$ \\
\hline pH & $5-7$ & 6,01 & 6,51 & 6,49
\end{tabular}

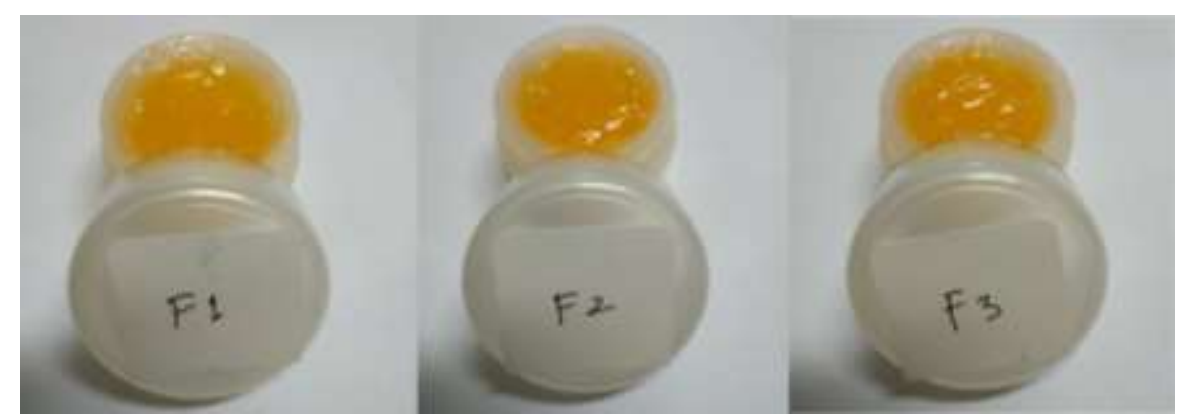

Gambar 1. Hasil Produk Awal

Uji stabilitas pada suhu kamar selama 12 minggu memberikan hasil stabil untuk 3 formula sampai minggu ke-8, namun pada minggu ke-12 ada perubahan warna sedikit pudar pada formula 2 dan formula 3, hal ini bisa disebabkan pengaruh dari parfum yang bereaksi dengan astaxhantin yang memberikan warna orange terhadap produk. Hasil pemeriksaan lain memberikan hasil yang sesuai spesifikasi Hasil pemeriksaan dapat dilihat pada tabel 3 dan gambar 2 . 
Tabel 3. Hasil Pemeriksaan Stabilitas pada Suhu Kamar

\begin{tabular}{|c|c|c|c|c|c|c|}
\hline Waktu (Minggu) & Formula & Bentuk & Warna & Bau & $\mathrm{pH}$ & Viskositas \\
\hline \multirow{3}{*}{0} & 1 & Tidak berubah & Tidak berubah & Tidak berbau & Sesuai Spek & Sesuai Spek \\
\hline & 2 & Tidak berubah & Tidak berubah & Tidak berbau & Sesuai Spek & Sesuai Spek \\
\hline & 3 & Tidak berubah & Tidak berubah & Tidak berbau & Sesuai Spek & Sesuai Spek \\
\hline \multirow{3}{*}{1} & 1 & Tidak berubah & Tidak berubah & Tidak berbau & Sesuai Spek & Sesuai Spek \\
\hline & 2 & Tidak berubah & Tidak berubah & Tidak berbau & Sesuai Spek & Sesuai Spek \\
\hline & 3 & Tidak berubah & Tidak berubah & Tidak berbau & Sesuai Spek & Sesuai Spek \\
\hline \multirow{3}{*}{2} & 1 & Tidak berubah & Tidak berubah & Tidak berbau & Sesuai Spek & Sesuai Spek \\
\hline & 2 & Tidak berubah & Tidak berubah & Tidak berbau & Sesuai Spek & Sesuai Spek \\
\hline & 3 & Tidak berubah & Tidak berubah & Tidak berbau & Sesuai Spek & Sesuai Spek \\
\hline \multirow{3}{*}{3} & 1 & Tidak berubah & Tidak berubah & Tidak berbau & Sesuai Spek & Sesuai Spek \\
\hline & 2 & Tidak berubah & Tidak berubah & Tidak berbau & Sesuai Spek & Sesuai Spek \\
\hline & 3 & Tidak berubah & Tidak berubah & Tidak berbau & Sesuai Spek & Sesuai Spek \\
\hline \multirow{3}{*}{4} & 1 & Tidak berubah & Tidak berubah & Tidak berbau & Sesuai Spek & Sesuai Spek \\
\hline & 2 & Tidak berubah & Tidak berubah & Tidak berbau & Sesuai Spek & Sesuai Spek \\
\hline & 3 & Tidak berubah & Tidak berubah & Tidak berbau & Sesuai Spek & Sesuai Spek \\
\hline \multirow{3}{*}{8} & 1 & Tidak berubah & Tidak berubah & Tidak berbau & Sesuai Spek & Sesuai Spek \\
\hline & 2 & Tidak berubah & Tidak berubah & Tidak berbau & Sesuai Spek & Sesuai Spek \\
\hline & 3 & Tidak berubah & Tidak berubah & Tidak berbau & Sesuai Spek & Sesuai Spek \\
\hline \multirow{3}{*}{12} & 1 & Tidak berubah & Tidak berubah & Tidak berbau & Sesuai Spek & Sesuai Spek \\
\hline & 2 & Tidak berubah & Sedikit Pudar & Tidak berbau & Sesuai Spek & Sesuai Spek \\
\hline & 3 & Tidak berubah & Sedikit Pudar & Tidak berbau & Sesuai Spek & Sesuai Spek \\
\hline
\end{tabular}

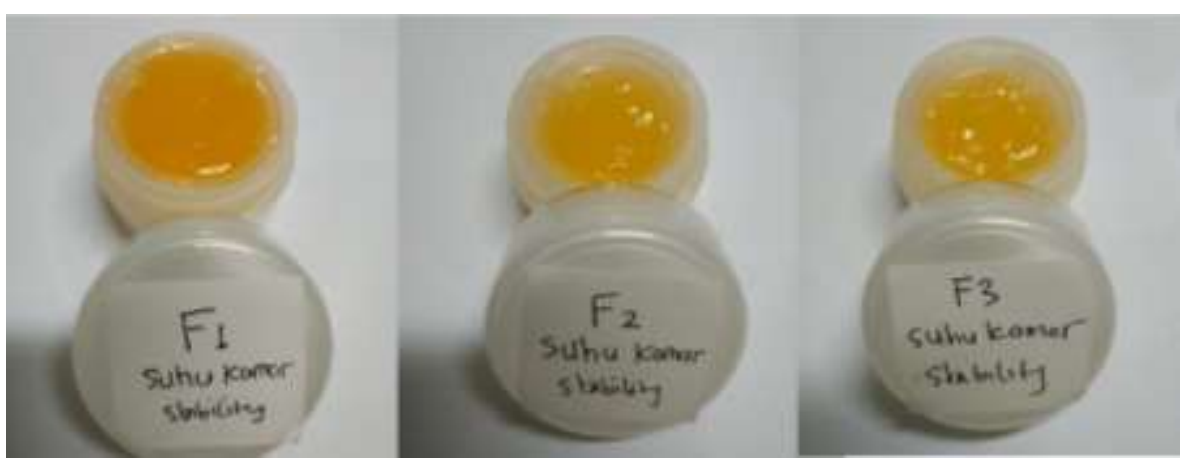

Gambar 2. Hasil Uji Stabilitas Produk Selama 12 Minggu pada Suhu Kamar 
Uji stabilitas pada suhu $40^{\circ} \mathrm{C}$ selama 12 minggu memberikan hasil tidak stabil pada formula 2 dan 3 pada minggu ke 4 sampai minggu ke- 8 yang memberikan warna produk sedikit pudar dan pada minggu ke-12 warna menjadi pudar. Hasil pemeriksaan lain memberikan hasil yang sesuai spesifikasi. Hasil pemeriksaan dapat dilihat pada tabel 4 dan gambar 3.

Tabel 4. Hasil Pemeriksaan Stabilitas pada Suhu $40^{\circ} \mathrm{C}$

\begin{tabular}{|c|c|c|c|c|c|c|}
\hline Waktu (Minggu) & Formula & Bentuk & Warna & Bau & $\mathrm{pH}$ & Viskositas \\
\hline \multirow{3}{*}{0} & 1 & Tidak berubah & Tidak berubah & Tidak berbau & Sesuai Spek & Sesuai Spek \\
\hline & 2 & Tidak berubah & Tidak berubah & Tidak berbau & Sesuai Spek & Sesuai Spek \\
\hline & 3 & Tidak berubah & Tidak berubah & Tidak berbau & Sesuai Spek & Sesuai Spek \\
\hline \multirow{3}{*}{1} & 1 & Tidak berubah & Tidak berubah & Tidak berbau & Sesuai Spek & Sesuai Spek \\
\hline & 2 & Tidak berubah & Tidak berubah & Tidak berbau & Sesuai Spek & Sesuai Spek \\
\hline & 3 & Tidak berubah & Tidak berubah & Tidak berbau & Sesuai Spek & Sesuai Spek \\
\hline \multirow{3}{*}{2} & 1 & Tidak berubah & Tidak berubah & Tidak berbau & Sesuai Spek & Sesuai Spek \\
\hline & 2 & Tidak berubah & Tidak berubah & Tidak berbau & Sesuai Spek & Sesuai Spek \\
\hline & 3 & Tidak berubah & Tidak berubah & Tidak berbau & Sesuai Spek & Sesuai Spek \\
\hline \multirow{3}{*}{3} & 1 & Tidak berubah & Tidak berubah & Tidak berbau & Sesuai Spek & Sesuai Spek \\
\hline & 2 & Tidak berubah & Tidak berubah & Tidak berbau & Sesuai Spek & Sesuai Spek \\
\hline & 3 & Tidak berubah & Tidak berubah & Tidak berbau & Sesuai Spek & Sesuai Spek \\
\hline \multirow{3}{*}{4} & 1 & Tidak berubah & Tidak berubah & Tidak berbau & Sesuai Spek & Sesuai Spek \\
\hline & 2 & Tidak berubah & Sedikit pudar & Tidak berbau & Sesuai Spek & Sesuai Spek \\
\hline & 3 & Tidak berubah & Sedikit pudar & Tidak berbau & Sesuai Spek & Sesuai Spek \\
\hline \multirow{3}{*}{8} & 1 & Tidak berubah & Tidak berubah & Tidak berbau & Sesuai Spek & Sesuai Spek \\
\hline & 2 & Tidak berubah & Sedikit pudar & Tidak berbau & Sesuai Spek & Sesuai Spek \\
\hline & 3 & Tidak berubah & Sedikit pudar & Tidak berbau & Sesuai Spek & Sesuai Spek \\
\hline \multirow{3}{*}{12} & 1 & Tidak berubah & Tidak berubah & Tidak berbau & Sesuai Spek & Sesuai Spek \\
\hline & 2 & Tidak berubah & Pudar & Tidak berbau & Sesuai Spek & Sesuai Spek \\
\hline & 3 & Tidak berubah & Pudar & Tidak berbau & Sesuai Spek & Sesuai Spek \\
\hline
\end{tabular}




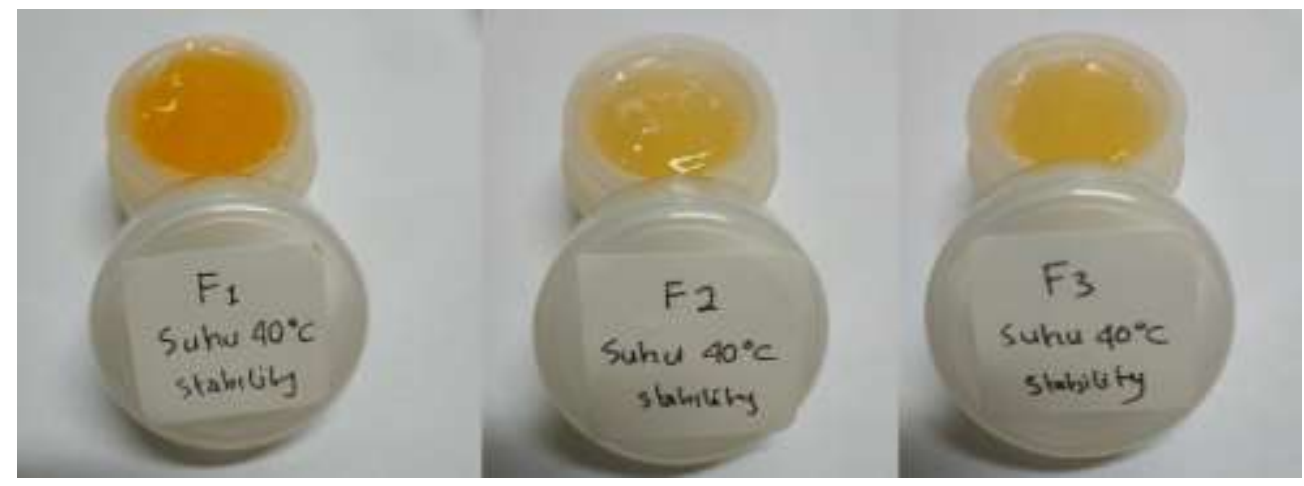

Gambar 3. Hasil Uji Stabilitas Produk Selama 12 Minggu pada Suhu $40^{\circ} \mathrm{C}$

Uji stabilitas pada sinar matahari selama 12 minggu memberikan hasil tidak stabil pada formula 2 dan 3 pada minggu ke-4 yang memberikan warna produk sedikit pudar, pudar pada minggu ke-8 dan pada minggu ke-12 warna menjadi tidak berwarna. Hasil pemeriksaan lain memberikan hasil yang sesuai spesifikasi. Hasil pemeriksaan dapat dilihat pada tabel 5 dan gambar 4.

Tabel 5. Hasil Pemeriksaan Stabilitas pada Sinar Matahari

\begin{tabular}{|c|c|c|c|c|c|c|}
\hline Waktu (Minggu) & Formula & Bentuk & Warna & $\mathrm{Bau}$ & $\mathrm{pH}$ & Viskositas \\
\hline \multirow{3}{*}{0} & 1 & Tidak berubah & Tidak berubah & Tidak berbau & Sesuai Spek & Sesuai Spek \\
\hline & 2 & Tidak berubah & Tidak berubah & Tidak berbau & Sesuai Spek & Sesuai Spek \\
\hline & 3 & Tidak berubah & Tidak berubah & Tidak berbau & Sesuai Spek & Sesuai Spek \\
\hline \multirow{3}{*}{1} & 1 & Tidak berubah & Tidak berubah & Tidak berbau & Sesuai Spek & Sesuai Spek \\
\hline & 2 & Tidak berubah & Tidak berubah & Tidak berbau & Sesuai Spek & Sesuai Spek \\
\hline & 3 & Tidak berubah & Tidak berubah & Tidak berbau & Sesuai Spek & Sesuai Spek \\
\hline \multirow{3}{*}{2} & 1 & Tidak berubah & Tidak berubah & Tidak berbau & Sesuai Spek & Sesuai Spek \\
\hline & 2 & Tidak berubah & Tidak berubah & Tidak berbau & Sesuai Spek & Sesuai Spek \\
\hline & 3 & Tidak berubah & Tidak berubah & Tidak berbau & Sesuai Spek & Sesuai Spek \\
\hline \multirow{3}{*}{3} & 1 & Tidak berubah & Tidak berubah & Tidak berbau & Sesuai Spek & Sesuai Spek \\
\hline & 2 & Tidak berubah & Tidak berubah & Tidak berbau & Sesuai Spek & Sesuai Spek \\
\hline & 3 & Tidak berubah & Tidak berubah & Tidak berbau & Sesuai Spek & Sesuai Spek \\
\hline \multirow{3}{*}{4} & 1 & Tidak berubah & Tidak berubah & Tidak berbau & Sesuai Spek & Sesuai Spek \\
\hline & 2 & Tidak berubah & Sedikit pudar & Tidak berbau & Sesuai Spek & Sesuai Spek \\
\hline & 3 & Tidak berubah & Sedikit pudar & Tidak berbau & Sesuai Spek & Sesuai Spek \\
\hline 8 & 1 & Tidak berubah & Tidak berubah & Tidak berbau & Sesuai Spek & Sesuai Spek \\
\hline
\end{tabular}




\begin{tabular}{ccccccc}
\hline & 2 & Tidak berubah & Pudar & Tidak berbau & Sesuai Spek & Sesuai Spek \\
\cline { 2 - 6 } & 3 & Tidak berubah & Pudar & Tidak berbau & Sesuai Spek & Sesuai Spek \\
\hline \multirow{3}{*}{12} & Tidak berubah & Tidak berubah & Tidak berbau & Sesuai Spek & Sesuai Spek \\
\cline { 2 - 6 } & & Tidak berubah & Tidak Berwarna & Tidak berbau & Sesuai Spek & Sesuai Spek \\
\hline & & Tidak berubah & Tidak Berwarna & Tidak berbau & Sesuai Spek & Sesuai Spek \\
\hline
\end{tabular}

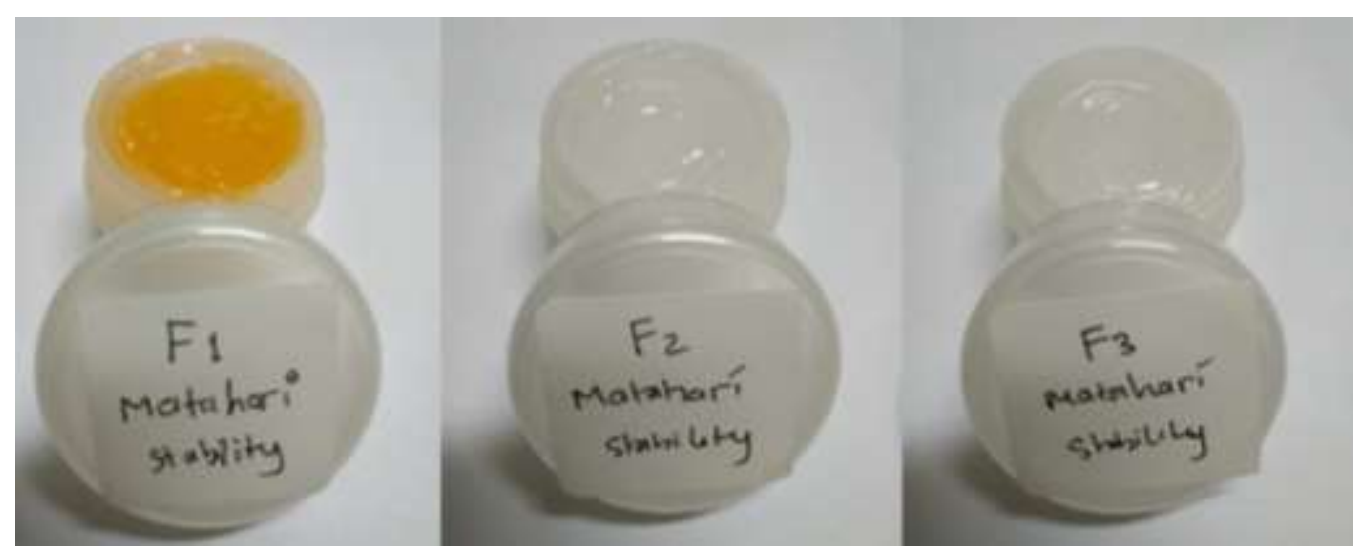

Gambar 4. Hasil Uji Stabilitas Produk Selama 12 Minggu pada Sinar Matahari

Uji kompatibilitas selama 12 minggu dilakukan pada formula 1 menggunakan kemasan yang akan dipasarkan dengan kondisi penyimpanan disuhu kamar, suhu $40^{\circ} \mathrm{C}$ dan pada sinar matahari dengan pemeriksaan organoleptis, bobot, $\mathrm{pH}$ dan viskositas. Uji kompatibilitas hanya dilakukan untuk formula 1 karena formula1 memberikan uji stabilitas yang baik dibanding formula 2 dan 3. Dari hasil pemeriksaan didapat bahwa penggunaan kemasan pot yang dipilih sebagai kemasan untuk produk akhir tidak memberikan pengaruh terhadap produk karena dari 3 kondisi penyimpanan selama 12 minggu produk masih stabil dan tidak terjadi penyusutan bobot yang signifikan. Hasil pemeriksaan dapat dilihat pada tabel 6, 7,8 dan gambar 5. 
Tabel 6. Hasil Pemeriksaan Kompatibilitas Pada Suhu Kamar

\begin{tabular}{|c|c|c|c|c|c|c|}
\hline Waktu (Minggu) & Bobot & Bentuk & Warna & Bau & $\mathrm{pH}$ & Viskositas \\
\hline 0 & $131,32 \mathrm{gr}$ & Tidak berubah & Tidak berubah & Tidak berbau & Sesuai Spek & Sesuai Spek \\
\hline 1 & $131,32 \mathrm{gr}$ & Tidak berubah & Tidak berubah & Tidak berbau & Sesuai Spek & Sesuai Spek \\
\hline 2 & $131,30 \mathrm{gr}$ & Tidak berubah & Tidak berubah & Tidak berbau & Sesuai Spek & Sesuai Spek \\
\hline 3 & $131,30 \mathrm{gr}$ & Tidak berubah & Tidak berubah & Tidak berbau & Sesuai Spek & Sesuai Spek \\
\hline 4 & $131,30 \mathrm{gr}$ & Tidak berubah & Tidak berubah & Tidak berbau & Sesuai Spek & Sesuai Spek \\
\hline 8 & $131,27 \mathrm{gr}$ & Tidak berubah & Tidak berubah & Tidak berbau & Sesuai Spek & Sesuai Spek \\
\hline 12 & $131,25 \mathrm{gr}$ & Tidak berubah & Tidak berubah & Tidak berbau & Sesuai Spek & Sesuai Spek \\
\hline
\end{tabular}

Tabel 7. Hasil Pemeriksaan Kompatibilitas pada Suhu $40^{\circ} \mathrm{C}$

\begin{tabular}{ccccccc}
\hline Waktu (Minggu) & Bobot & Bentuk & Warna & Bau & pH & Viskositas \\
\hline 0 & $133,33 \mathrm{gr}$ & Tidak berubah & Tidak berubah & Tidak berbau & Sesuai Spek & Sesuai Spek \\
\hline 1 & $133,33 \mathrm{gr}$ & Tidak berubah & Tidak berubah & Tidak berbau & Sesuai Spek & Sesuai Spek \\
\hline 2 & $133,25 \mathrm{gr}$ & Tidak berubah & Tidak berubah & Tidak berbau & Sesuai Spek & Sesuai Spek \\
\hline 3 & $133,25 \mathrm{gr}$ & Tidak berubah & Tidak berubah & Tidak berbau & Sesuai Spek & Sesuai Spek \\
\hline 4 & $133,22 \mathrm{gr}$ & Tidak berubah & Tidak berubah & Tidak berbau & Sesuai Spek & Sesuai Spek \\
\hline 8 & $133,16 \mathrm{gr}$ & Tidak berubah & Tidak berubah & Tidak berbau & Sesuai Spek & Sesuai Spek \\
\hline 12 & $133,09 \mathrm{gr}$ & Tidak berubah & Tidak berubah & Tidak berbau & Sesuai Spek & Sesuai Spek \\
\hline
\end{tabular}

Tabel 8. Hasil Pemeriksaan Kompatibilitas pada Sinar Matahari

\begin{tabular}{|c|c|c|c|c|c|c|}
\hline Waktu (Minggu) & Bobot & Bentuk & Warna & Bau & $\mathrm{pH}$ & Viskositas \\
\hline 0 & $131,20 \mathrm{gr}$ & Tidak berubah & Tidak berubah & Tidak berbau & Sesuai Spek & Sesuai Spek \\
\hline 1 & $131,20 \mathrm{gr}$ & Tidak berubah & Tidak berubah & Tidak berbau & Sesuai Spek & Sesuai Spek \\
\hline 2 & $131,14 \mathrm{gr}$ & Tidak berubah & Tidak berubah & Tidak berbau & Sesuai Spek & Sesuai Spek \\
\hline 3 & $131,19 \mathrm{gr}$ & Tidak berubah & Tidak berubah & Tidak berbau & Sesuai Spek & Sesuai Spek \\
\hline 4 & $131,17 \mathrm{gr}$ & Tidak berubah & Tidak berubah & Tidak berbau & Sesuai Spek & Sesuai Spek \\
\hline 8 & $131,17 \mathrm{gr}$ & Tidak berubah & Tidak berubah & Tidak berbau & Sesuai Spek & Sesuai Spek \\
\hline 12 & $131,16 \mathrm{gr}$ & Tidak berubah & Tidak berubah & Tidak berbau & Sesuai Spek & Sesuai Spek \\
\hline
\end{tabular}

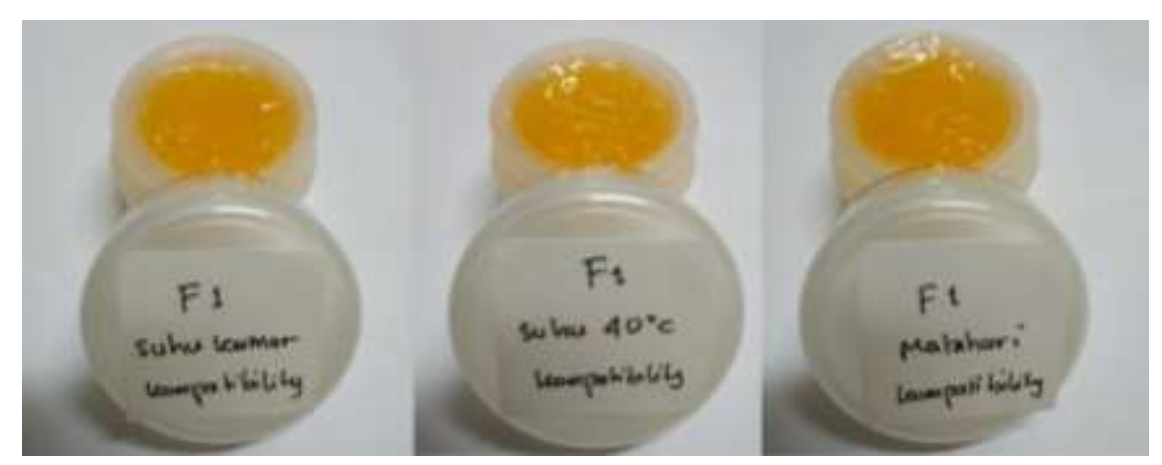

Gambar 5. Hasil Uji Kompatibilitas Produk Selama 12 Minggu 


\section{KESIMPULAN}

Polimer dapat dimanfaatkan sebagai sediaan serum berbentuk Pudding untuk produk kosmetik anti-aging dengan konsentrasi 5\%. Formula F1, F2 dan F3 memberikan hasil yang baik pada saat dibuat. Formula F1 memberikan hasil yang stabil sedangkan Formula F2 dan F3 memberikan hasil yang tidak stabil dikarenakan warna produk sedikit pudar sampai tidak berwarna pada 3 kondisi penyimpanan yaitu pada suhu kamar, suhu $40^{\circ} \mathrm{C}$ dan dibawah sinar matahari, hal ini bisa disebabkan karena pengaruh parfum pada Formula F2 dan F3 yang mempengaruhi kestabilan dari warna alami produk dari bahan astaxhantin. Pada uji kompatibilitas antara kemasan produk akhir dengan produk, formula F1 memberikan hasil yang baik, dari hasil pemeriksaan kemasan yang dipakai tidak mempengaruhi kestabilan produk dan tidak menurunkan bobot produk secara signifikan. 


\section{DAFTAR PUSTAKA}

Barel, A.O., Paye, M., and Maibach, H.I. 2009. Handbook of Cosmetic Science and Technology, ${ }^{3 \mathrm{rd}}$ Edition., Informa Healthcare USA, Inc., New York.

Badan Pengawas Obat dan Makanan. 2003. Keputusan Kepala Badan Pengawas Obat dan Makanan Republik Indonesia Nomor Hk.00.05.4.1745 Tahun 2003, Tentang Kosmetik, Kepala Badan Pengawas Obat dan Makanan, Jakarta.

Badan Pengawas Obat dan Makanan. 2010. Peraturan kepala Badan Pengawas Obat dan Makanan Republik Indonesia nomor: Hk. 03.42.06.10.4556 Tahun 2010, tentang Petunjuk Operasional Pedoman Cara Pembuatan Kosmetik yang Baik, Kepala Badan Pengawas Obat dan Makanan, Jakarta.

Kurniawati, Azizah Yunita. 2018. Karakteristik Sediaan Serum Wajah Dengan Variasi Konsentrasi Sari Rimpang Temu Giring (Curcuma heyneana) Terfermentasi Lactobacillus bulgaricus. Karya Tulis Ilmiah. Akademi Farmasi Putra Indonesia Malang, Malang.

Muliyawan, D., dan Suriana, N. 2013. A-Z Tentang Kosmetik, PT Elex Media Komputindo, Jakarta.

Primadiati, R. 2001. Kecantikan Kosmetika dan Estetika. PT. Gramedia Pustaka Utama, Jakarta.

Tranggono dan Latifah. 2007. Buku Pegangan Ilmu Pengetahuan Kosmetik, Editor: Jhosita Djadjadisastra. Penerbit Pustaka Utama, Jakarta. 